\title{
Assessment of Faecal Sludge Management in Nguru Town, Yobe State, Northeastern Nigeria
}

\author{
M.Z.Karkarna and Muktar Adamu \\ Department of Environmental Management, Bayero University Kano, Nigeria \\ Corresponding author email: mzkarkarna@gmail.com
}

\begin{abstract}
The aim of the study is to assess faecal sludge management (FSM) in Nguru town, Nguru Local Government area of Yobe State. Random sampling method was used in the selection of respondents in six political wards of the study area. A total of 399 questionnaires were administered to respondents in the study area with the view to identify the types and current practices of faecal sludge management in the study area. The result of the study indicates that majority of the respondents $68 \%$ used pit latrine, $24 \%$ used water closet while $8 \%$ used other type of toilet facilities. However, on the excreta defecation, the finding indicated that $84 \%$ had access to household toilets, $8.0 \%$ used public toilets, and $6.0 \%$ practiced open defecation with the remaining $2 \%$ practicing defecation in polythene bags after which they discard it into the bush or on a refuse dump. The study further revealed that majority (54\%) of the respondents disposed their toilet sludge by land fill, 31\% participants were using any available land for faecal sludge final disposal while $10 \%$ and $5 \%$ disposed their toilet by nearby river and composting respectively. The finding indicated that, the faecal sludge management of the study area is unsatisfactory and may pose a risk of environmental and adverse human health. The current practices of faecal sludge management were found below international standard requirement set by WHO. It is therefore recommend that Government should come up with proper orientation and environmental laws should be put in place for the general public and also to provide necessary facilities and arrange for better methods of faecal sludge management.

Kevwords: FSM. Nouru town. Toilet facilities and onen defecation
\end{abstract}

\section{INTRODUCTION}

Excreta are a part of everyday life. Every adult human being produces $130 \mathrm{~g}$ of faeces and $1.4 \mathrm{~L}$ of urine every day (Rose et al. 2015). The negative part of all these excreta is that if it is not managed properly, these waste products cause waterborne diseases and water pollution, and a lack of access to clean, functioning toilets threatens human dignity. And that is the case for 2.4 billion people worldwide without access to sanitary toilets (UNICEF \& WHO, 2015). Africa (including Nigeria) recorded the least progress, with use of improved sanitation increasing from 26 percent in 1990 to 31 percent in 2006 (WHO and UNICEF, 2008).

In response to the lack of access to basic sanitation, the United Nations defined the target of Goal 7 of the Millennium Development Goals (i.e., MDGs) to halve the proportion of the population without access to improved sanitation facilities1 during the period from 1990 to 2015 (United Nations 2015). Unfortunately, it was not achieved. However, now the Sustainable Development Goals (i.e., SDGs) in September 2015 have defined a new target to achieve access to adequate and equitable sanitation and hygiene for all and end open defecation by 2030 (United Nations Department of Economic and Social Affairs, 2015).

Poor sanitation has differential impacts on the health of men, women, boys and girls as well as broad economic and environmental implications. Access to sanitation facilities remains a challenge for urban populations in many sub-Saharan African cities, particularly for people living in poor peri urban areas. Socioeconomic status and settlement characteristics are the main indicators of access to reliable water and sanitation in periurban settlements (Angoua et al., 2018). While a lack of sanitation facilities reflects the lack of services in urban and peri-urban spaces, community members bear some responsibility for their environment and health. For example, unauthorized temporary structures, discharging wastewater and excreta into public spaces, dumping garbage near households, and open defecation all contribute to environmental and health risks (Angoua et al., 2018). 
UJMR, Volume 6 Number 1, June, 2021, pp 1 - 10

Inadequate sanitation is the root cause of many tropical diseases, with improper faecal sludge management and poor sanitation contributing to the 115 deaths per hour from excretarelated diseases in Africa (Chowdhry and Koné, 2012; Mara et al., 2010). While faecal sludge is rich in nitrogen, phosphorus, potassium and organic matter, it also contains high counts of pathogenic coliforms, E. coli and helminth eggs (Pradhan, 2016; Strande et al., 2014). Contact with as little as one gram of fresh faeces exposes a person to as many as 106 viral pathogens, 106-108 bacterial pathogens, 104 protozoan cysts or oocysts, and 10-104 helminth eggs (Thaku et al., 2018).

In Nigeria, like many other developing countries across the globe, contends with enormous global and local environmental problems. Government has been making efforts to tackle most of the environmental issues both solely and in partnership with donor agencies, but surprisingly it is largely negligent in faecal sludge management (FSM). There is no state in Nigeria with a coordinated structure of managing faecal sludge, except the FCT perhaps. Most states seem to care less what becomes of faecal wastes they generate. They do not insist on designated locations for Faecal Sludge disposal and faecal wastes are therefore indiscriminately disposed in water bodies, bushes or in gullies. These open dumps cause a lot of health hazards and reduce the beauty value of the surrounding environment and also contaminate the natural resources. Numerous studies have been conducted on environmental sanitation in Yobe and others state of Nigeria, but relatively only few studies were carried outon faecal sludge management. Therefore, the objective of this work is to assess faecal sludge management practices in some parts of Nguru town, Nguru Local Government, Yobe State, Nigeria.

\section{MATERIALS AND METHODS}

STUDY AREA

Nguru town is head quarter of Nguru Local Government Area (LGA) in Yobe state, northern Nigeria. It is located near river Hadejia at $12^{\circ}$ $52^{\prime} 45^{\prime \prime} \mathrm{N}$ to $10^{\circ} 27^{\prime} 09^{\prime \prime} \mathrm{E}$. It has population of 150,632 (Census, 2006) with projection of 213,900 population, an area of $916 \mathrm{sq}, \mathrm{km}$ (census 2006). The topography of Nguru is mainly flat with a variety of landscapes as Hadejia-Nguru wetlands of Nguru Lake and the Sand dunes around machine road. Nguru has hot and dry climate throughout the year.

\section{METHODOLOGY}

The Study adopted combinations of desk study and literature reviews, questionnaire administration and field observations. The field data have collected using survey research method, involving the use of questionnaire and interview technique in obtaining information about the nature, practices and consequences poor faecal sludge management. Purposive sampling was used in the selection of areas of study within the Nguru town. Seven areas (Bulabulin, Hausari, tsohon guru, Sabon garinkanuri, Garbi and Dumsai wards) were purposively selected due in-appropriate designation locations for Faecal Sludge disposal in these area. A Random sampling was used in the selection of participants from the sampling frame which was obtained using purposive sampling techniques. Sample size was determined by using Yaro Yamane (1963) sample size determination formula, which is stated below as follows;

$\mathrm{n}=\mathrm{N} / 1+\mathrm{N}(\mathrm{E})^{2}$

Where: $\mathrm{n}=$ the sample size to be determined; $\mathrm{N}$ $=$ the population of the study. $\mathrm{e}=$ Limit of the error acceptable for the study $=5 \% ; 1=$ constant. Therefore, $\mathrm{N}=150,632$ because Nguru local government areas has a population of 150,632 according to 2006 (NPC, 2006 Census) $\mathrm{n}=\mathrm{N} / 1+\mathrm{N}(\mathrm{E})^{2}=150632 / 1+150632(0.05)^{2}=$ 399 .

Thus, 399 questionnaires were distributed in all out of which 279 were duly completed and returned.

Frequency and percentage were used to analyze the data. The result was presented in form table and charts were also produced using SPSS. The data were presented in tables and charts were also produced using excel

\section{RESULT AND DISCUSSION}

Table 1 shows the demographic characteristics of the respondents where more than three quarter of the respondents were age 21 and above indicating that majority of the residents are youth and within their active age. The result also revealed that half of the respondents were males. The overwhelming majority are married which constituted $(72.7 \%)$ respondents. These findings agree with finding of National Health and Demographic Survey (NDHS, 2018). The level of education of the residents is generally low, only a few of the respondents constituted $(23 \%)$ have tertiary education while majority attend Quranic schools only. 
Table 4.1 Demographic Profile of the Respondents

\begin{tabular}{llll}
\hline Characteristics & Respondents & Frequency & Percentage \\
\hline & Below 20 & 36 & 13.0 \\
& $21-40$ & 58 & 20.8 \\
Age & $41-50$ & 109 & 39.1 \\
& Above 50 & 76 & 27.1 \\
Gender & Total & 279 & 100 \\
\hline Marital Status & Female & 134 & 48.0 \\
& Male & 145 & 52.0 \\
& Total & 279 & 100.0 \\
\hline Level of Education & Married & 203 & 72.7 \\
& Single & 76 & 27.3 \\
& Total & 279 & 100.0 \\
\hline & Quranic & Below 20 & 39.1 \\
& Primary & $21-40$ & 16.5 \\
& Secondary & $41-60$ & 21.4 \\
& Tertiary & Above 60 & 23.0 \\
& Total & Total & 100 \\
\hline
\end{tabular}

Source: Field work, 2019.

Figures 1 indicate the toilet facilities used by the respondents in the study area. The result indicated that majority of the respondents $(94 \%)$ had access to toilet facilities while only $(6 \%)$ do not have toilet. The finding is in line with the World Bank Water and Sanitation Program on Faecal Sludge Management in 12 cities in Africa, Latin America, South Asia and East who reported that 64\% of the excreta in Urban and peri urban centres were processed by onsite sanitation technologies but only $22 \%$ was safely managed (World Bank Water Supply and Sanitation Program 2014). Access to toilet facilities is beneficial to households in terms of improved health status and gains in time saved for productive activities (Trémolet, 2013).

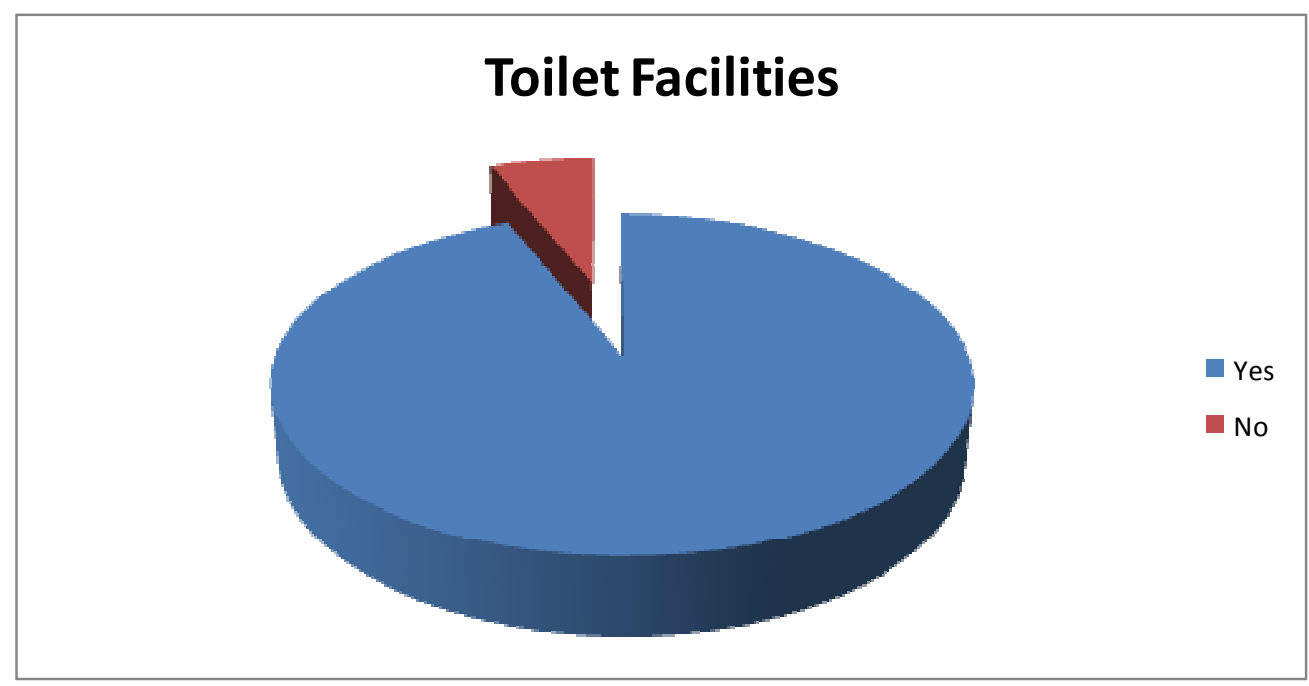

Figure 1: Toilet facilities of the Respondents in the Study area

Figure 2 shows different category of faecal sludge used in the study area. Majority of the respondents, $68 \%$ used pit latrine, $24 \%$ of the respondents used water closet while $8 \%$ respondents used other type of toilet facilities. This finding agrees with Murtala and Nafiu (2021) who reported that majority of the residents (52\%) in Fagoji area of Dutse used pit latrine. Also, in another study conducted by Antwi-Agye in Madina municipal, Ghana (2009) reported hat majority of the house hold toilet (47\%) were water closet followed by pit latrine which accounted $(27 \%)$ while only $3 \%$ respondents used bucket/pan latrine. Similarly, the work of Eawag/Sandec 2015 in Kampala stated that, the city is served mostly by pit latrines, a hole at the bottom of pit latrines is frequently made during the rainy season so that the faecal sludge directly drains out, resulting in direct discharge of faecal sludge in the environment 


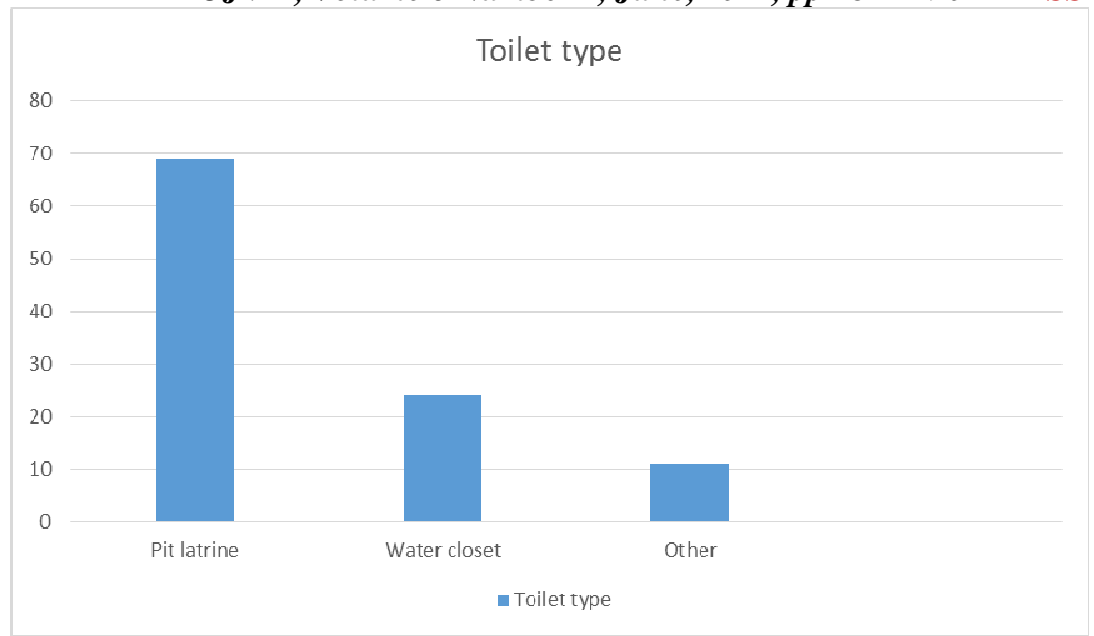

Figure 2 Type of Faecal sludge Management

Figure 3 shows defecation Practices adopted by respondents in the study area. The result indicated that $84 \%$ had access to household toilets, $8 \%$ used public toilets, $6 \%$ practiced open defaecation with the remaining $2 \%$ practicing defecation in polythene bags after which they discard it into the bush or on a refuse dump. This study is in line with Peal et al (2014) who analyzed Faecal sludge Management in 12 developing cities. The finding reported the extent of open defecation ranges from a high of $81 \%$ in Honduras (indicated here by $19 \%$ using open defecation) to a low of $9 \%$ in Kampala, Uganda (91\% on-site or open defecation) and the two smaller towns: Palu, Indonesia and Dumaguete, Philippines with no open defecation.

Some studies have reported that inaccessible sanitation designs force people with physical impairments to crawl on the floor to use a toilet or opt to defecate in the open. A high proportion of vulnerable household members have been found to be very reliant on others to use the toilet, sometimes soiling themselves while waiting, and many limit their consumption of food and water to reduce the need to relieve themselves (Wilbur and Jones, 2014). There are reported cases, though the exact estimate is not known, of people with disabilities being considered contagious and therefore prevented from using communal toilet facilities (Wilbur and Danquah, 2015

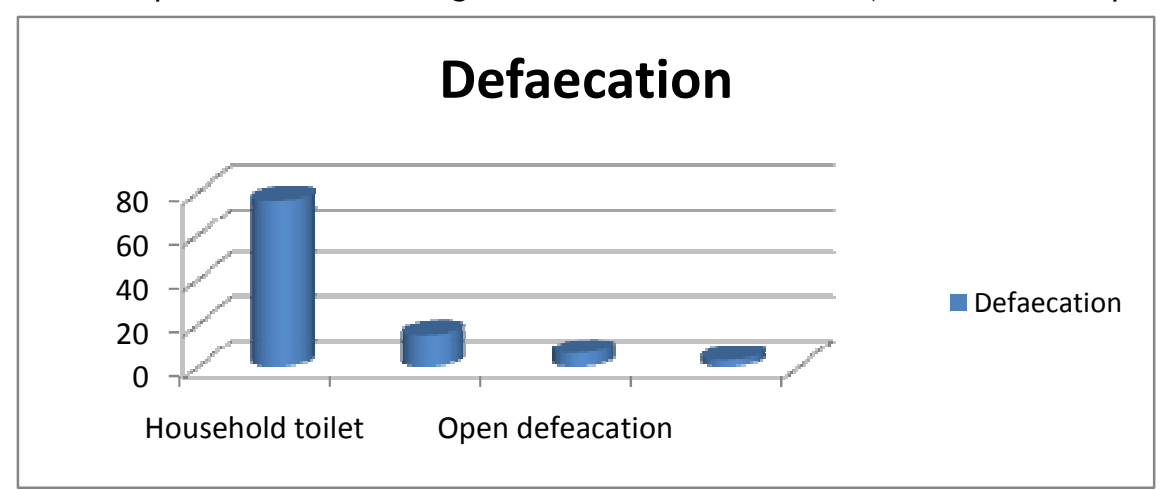

Figure 3 Defaecation Practices in Nguru Local Government

Figure 4 Shows that 160 respondents constitute $41 \%$ empty toilet by traditional digging, motor tank 80 respondents constitute $21 \%$, wheel barrow 90 respondents constitute $23 \%$, and replacement 54 respondents constitute $14 \%$. This study is inconsistent with the work of Jenkins et al., (2015) who reported that the widespread use of pit diversion ( 78 per cent), followed by tankers ( 58 per cent) and buckets (56 per cent) in empty toilet within Dar es Salaam, Tanzania. A recent study in Blantyre, Malawi revealed that most discharged sludge is taken from a small proportion of septic tanks in the city, while sludge from pit latrines (the most common sanitation technology) remains uncollected (Yesaya and Tilley, 2020). These findings support the need for appropriate businesses and infrastructures for faecal sludge management, including sustainable financing mechanisms to subsidize emptying services, which would make payment more affordable and encourage regulatory efforts to promote safe services (Jenkins et al., 2015). 


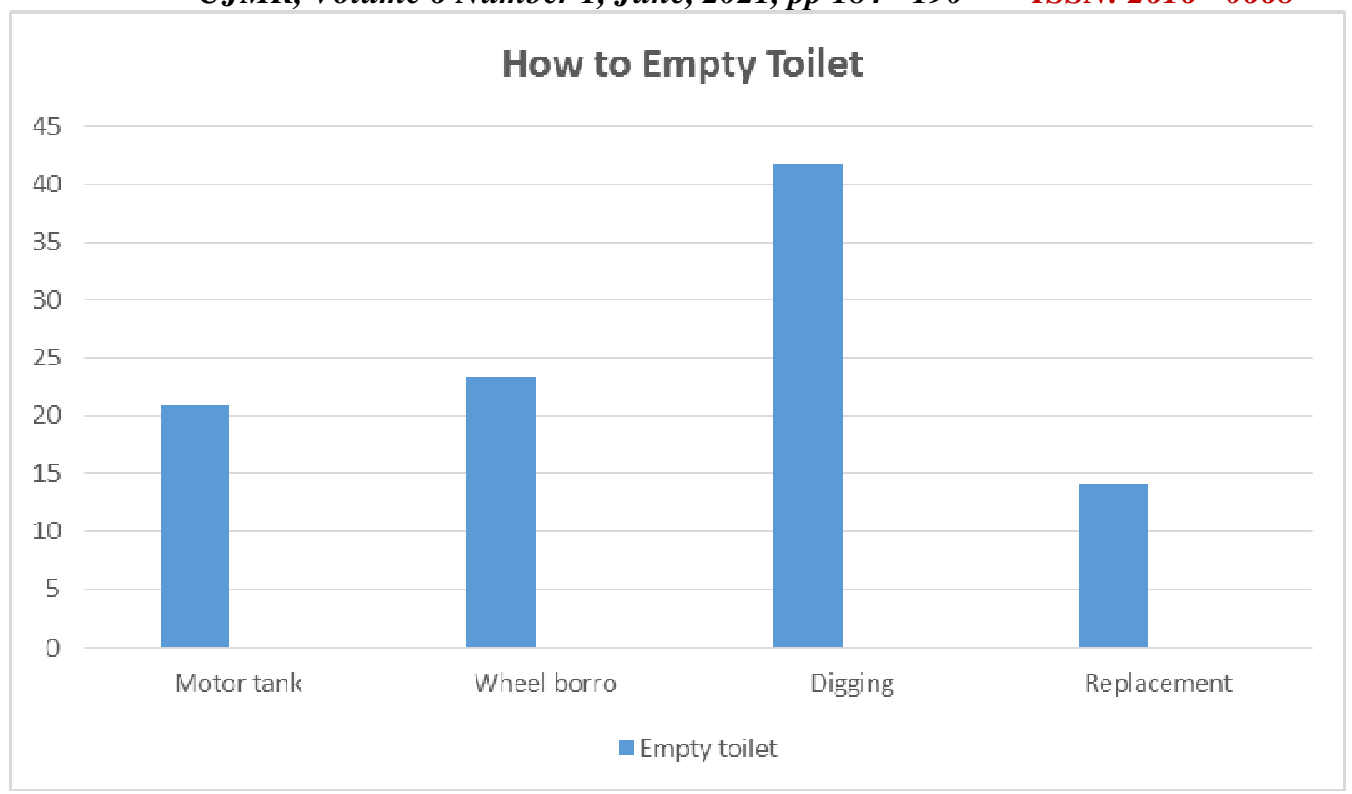

Figure 4: Methods of Emptying Toilet

Figure 5 shows the Faecal sludge treatment in the study area. Results showed that $22 \%$ of the people sprays petroleum in their faecal treatment ( $28 \%$ used izole for waste treatment) and $23 \%$ used traditional method of using ash in Nguru. Eighteen percent (26\%) of the respondents used composting in faecal treatment. The finding is line with the work of (Chowdhry and Koné, (2012) who identified poor faecal sludge treatment facilities in many African countries for financial reasons. Where available, existing facilities lack the capacity to treat the volume of faecal sludge generated or are very expensive to maintain. For example, in Addis Ababa, Ethiopia, the treatment plant has the capacity to receive only 67 per cent of the $530,000 \mathrm{~m} 3$ sludge collected annually.

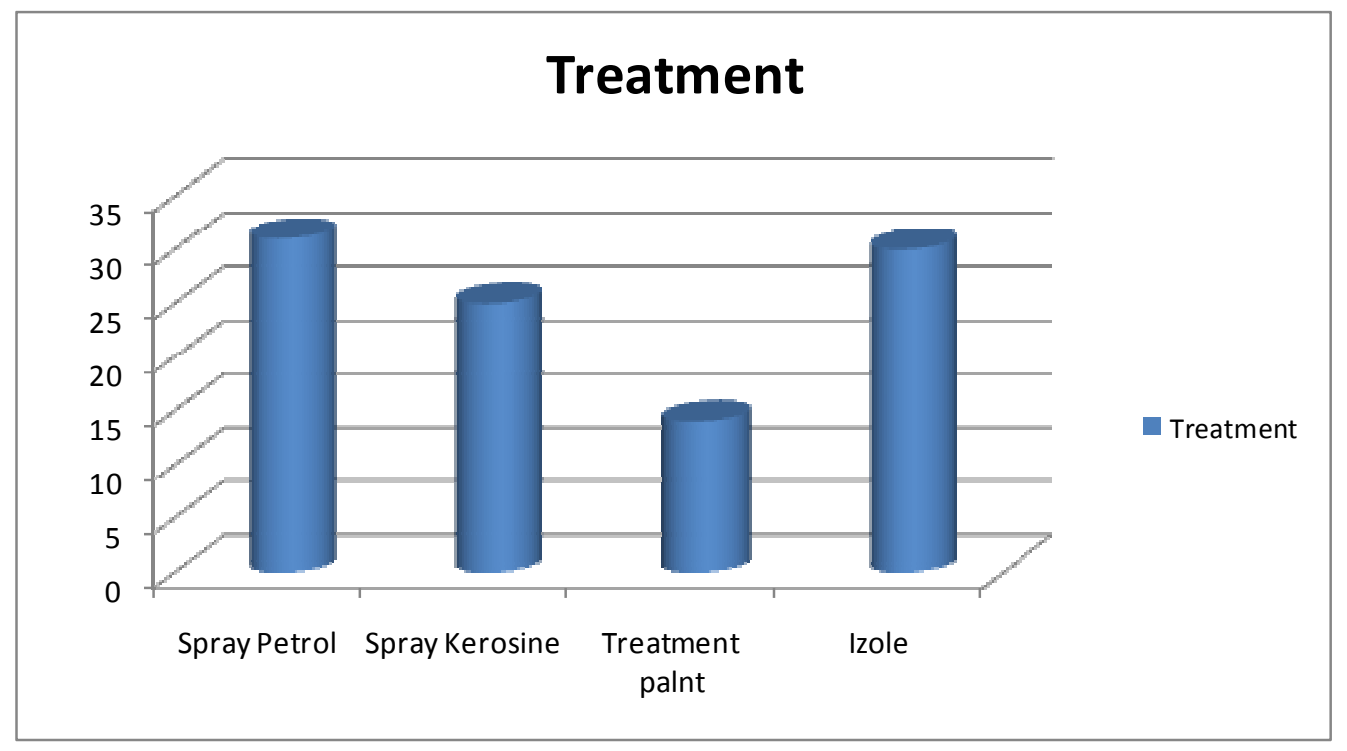

Figure 5 Faecal SludgeTreatment methods in Nguru

Figure 6 present different disposal strategy adopted by respondents in the study area. Majority $(54 \%)$ of them disposed their toilet sludge by land fill, $31 \%$ participants were using any available land for faecal sludge final disposal while $10 \%$ and $5 \%$ disposed their toilet by nearby river and composting respectively .The result of disposal methods obtained in this investigation is inconsistent with those reported by Mills, (2013) in Indonesia where the drain or sewer then discharges unsafely to the environment via a river or drain without treatment. 


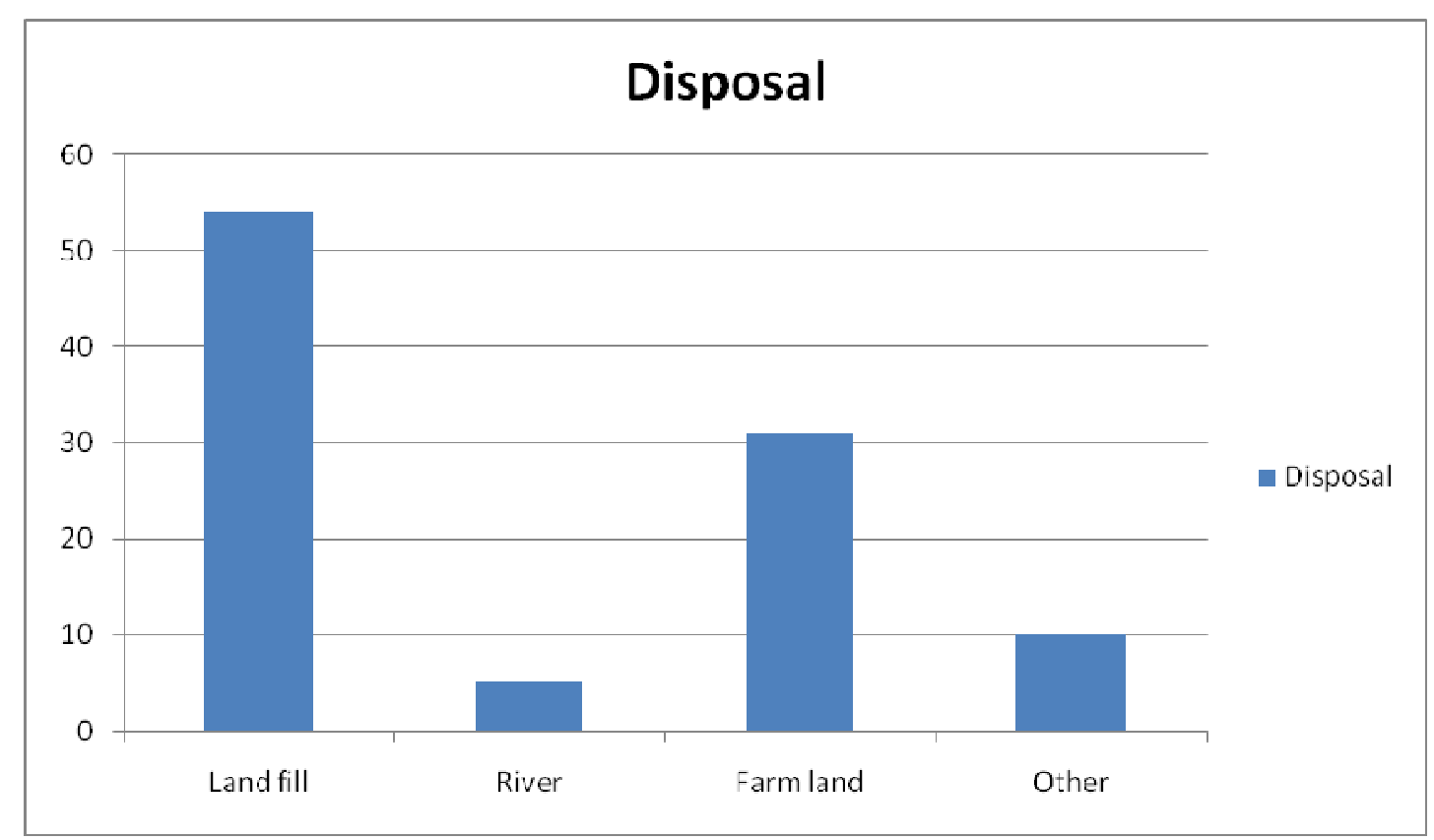

Figure 6: How household disposed their Toilet

\subsection{CONCLUSION}

The conclusion drawn from this limited study is that the management of faecal sludge would have to involve detailed study of the different form of practices and mitigate its risk of environmental and adverse human health. Furthermore, the faecal sludge management practices of Nguru town should be improves to

\section{REFERENCE}

Angoua, E.L.E., Dongo, K., Templeton, M.R., Zinsstag, J. and Bonfoh, B. (2018). Barriers to access improved water and sanitation in poor peri-urban settlements of Abidjan, Côte d'Ivoire. PloS one 13(8): e0202928, 1-13.

ANTWI-AGYEI, P. (2009) Faecal sludge management: the case of Madina. Kwame Nkrumah University of Science and Technology-KNUST MSc thesis Department of Water Supply and Environmental Sanitation

Chowdhry, S. and Kone, D. (2012). Business Analysis of Faecal Sludge Management: Emptying and Transportation Services in Africa and Asia. Draft Final Report. Sponsored by the Bill \& Melinda Gates Foundation, Seattle.

Eawag/Sandec (ed.) Brandes K, Schoebitz L, Kimwaga R, Strande L (2015a) SFD Promotion Initiative - Dar es Salaam, Tanzania, Report. Eawag/Sandec.

Jenkins, M. W., Cumming, O. and Cairncross, S. (2015). Pit latrine emptying behavior and demand for sanitation services in meet the standard requirement set by world health organization (WHO). It is therefore recommend that Government should come up with proper orientation and environmental laws should be put in place for the general public and also to provide necessary facilities and arrange for better methods of faecal sludge management.

Dar Es Salaam, Tanzania. International Journal of Environmental Research and Public Health 12(3), 2588-2611

Nikiema, J., Tanoh-Nguessan, R.,Abiola, F. and Cofie, O. O. (2020). Introducing CoComposting to Fecal Sludge Treatment Plants in Benin and Burkina Faso: A Logistical and Financial Assessment. Resource Recovery and Reuse Series 17. Colombo, Sri Lanka: IWMI, CGIAR Research Program on Water, Land and Ecosystems (WLE).

NDHS (2018). Nigeria Demographic and Health Survey, National population Commission Abuja Nigeria

Joint Monitoring Programme(JMP) (2019). Wash Data for 2017. https: / / washdata.org/data. Accessed 20 November 2019.

J-PAL (2012). J-PAL Urban Services Review Paper. Cambridge, MA: Abdul Latif Jameel Poverty Action Lab. http: / /econweb. umd.edu/ galiani/files/usi-reviewpaper.pd 
UJMR, Volume 6 Number 1, June, 2021, pp 184 - $190 \quad$ ISSN: 2616 - 0668

Mara,D.,Lane, J.,Scott, B. and Trouba,D.(2010). Sanitation and health. PLoSMed7(11):e1000363.https://doi.org /10.1371/journal.pmed.1000363.

Peal, A., Evans, B.E., Blackett, I., Hawkins, P. M. and Heymans, C. (2014). Faecal sludge management: analytical tools for assessing FSM in cities. Journal of Water, Sanitation \& Hygiene for Development 4(3), 371-383.

Strande, L, M. Ronteltap, and D. Brdjanovic (eds.) (2014). Faecal Sludge Management: Systems Approach for Implementation and Operation. London, UK: IWA Publishing.

Rose C, Parker a, Jefferson B, Cartmell E (2015) The characterization of feces and urine: a review of the literature to inform advanced treatment technology. Critical Reviews in Environmental Science and Technology 45(17): 18271879.

Trémolet, S. (2013). Sanitation economics: understanding why sanitation markets fail and how they can improve. Waterlines 32(4), 273-285.

Thakur, R., Singh, B. B., Jindal, P., Aulakh, R. S. and Gill, J. P. S. (2018). The Clean India Mission: Public and animal health benefits. Acta Tropica 186, 5-15

Wilbur, J. and Danquah, L. (2015). Undoing inequity: water, sanitation and hygiene programmes that deliver for all in Uganda and Zambia-an early indication of trends. 38th WEDC International Conference. Loughborough University, UK, 26 July-30 July 2015.

Wilbur, J. and Jones, H. (2014). Disability: Making CLTS fully inclusive. Frontiers of CLTS: Innovations and Insights (3). Brighton: IDS

UNICEF \& WHO (2015) Progress on Sanitation and Drinking Water - 2015 Update and MDG Assessment. Geneva: WHO Press.

United Nations Population Fund (UNFPA) (2016). The Demographic Profile of African Countries. Economic Commission for Africa.

https://www.uneca.org/sites/default/ files/PublicationFiles/demographic_pro file_rev_april_25.pdf

United Nations, Department of Economic and Social Affairs, Population Division (2015). World Urbanization Prospects: The 2014 Revision (Report No. ST/ESA/SER.A/366).

https://population.un.org/ wup/Publications/Files/WUP2014Report.pdf

Yesaya, M. and Tilley, E. (2020). Sludge bomb: The impending sludge emptying and treatment crisis in Blantyre, Malawi. Journal of Environmental Management, 277; 111474. 